\title{
A CHRISTIAN QUR'ĀN? A STUDY IN THE SYRIAC BACKGROUND TO THE LANGUAGE OF THE QUR'ĀN AS PRESENTED IN THE WORK OF CHRISTOPH LUXENBERG
}

\author{
Daniel King, Cardiff University (kingdh@cf.ac.uk)
}

\begin{abstract}
The present article is a contribution to the public debate surrounding the controversial thesis of an anonymous scholar known as Christoph Luxenberg. The thesis that a Syriac Christian literary source lies behind the text of the Qur'ān is not entirely new, but Luxenberg has presented it in a more forceful and comprehensive manner than ever before. The manifold responses to his work have mostly come from the arena of Islamic and Qur'ānic studies whereas the present article seeks to explore Luxenberg's work from the standpoint of Syriac philology. It demonstrates that his method is severely lacking in many areas, although he may on occasion have hit upon a useful emendation. Thus although the hypothesis as a whole is faulty, the individual textual suggestions ought to be treated on a case-by-case basis.
\end{abstract}

\section{Introduction}

The present paper constitutes a partial response to Christoph Luxenberg's The SyroAramaic Reading of the Koran. ${ }^{1}$ This book has achieved a certain notoriety among both specialist Arabists and at a more popular level, for suggesting that the origins of the Holy Book of Islam lie in a misunderstood Christian lectionary, written in an otherwise unattested form of Arabic heavily influenced by what he calls 'SyroAramaic', or even an 'Aramaic-Arabic hybrid language (Mischsprache)' [327]. ${ }^{2}$

${ }^{1}$ Christoph Luxenberg, The Syro-Aramaic Reading of the Koran: A Contribution to the Decoding of the Language of the Koran (Verlag Hans Schiler: Berlin, 2007). The current paper specifically targets this English-language edition of 2007, itself based on the second German edition of 2004 (the first edition was published in 2000). All numbers in [square brackets] refer to the pages of the 2007 English edition. References to the Qur'ān are given in (round brackets).

${ }^{2}$ Since what Luxenberg actually uses is almost always Syriac (he even admits, p.9, that this is exactly what Syro-Aramaic means, which rather begs the question of why he uses his invented term), i.e. the Edessene dialect of Eastern Aramaic, we shall generally refer to it by that name and leave aside a lengthy discussion into the eccentricities of Luxenberg's nomenclature, though he

Daniel King, 'A Christian Qur'ān? A Study in the Syriac background to the language of the Qur'ān as presented in the work of Christoph Luxenberg' in: Journal for Late Antique Religion and Culture 3 (2009) 44-71; ISSN: 1754-517X; Website: http://www.cardiff.ac.uk/clarc/jlarc 
Plenty of Arabists have responded, either with curt dismissals or with lengthier and sometimes more sympathetic readings. ${ }^{3}$ These, however, almost always focus on an assessment of the Arabic philological method used by Luxenberg. By contrast, there has been very little response from the side of Syriacists. ${ }^{4}$ The aim here, therefore, is to analyse in particular the Syriac philology to be found within the overall argument.

What follows is a series of notes and responses to the individual verses discussed in the book. It is of necessity somewhat unstructured since this is very much the nature of the book itself, but I have attempted broadly to organise it into meaningful sections.

The first six chapters (covering only 36 pages) are too general and introductory to be dealt with here, save for the 'working method' described in ch.3 which will be discussed below. Similarly, chs. 8,9 are very brief and general. Ch.7 introduces the reader to the importance of the 'imāla and of orthography in general and much of this is then used in ch.10 to deal with certain key Qur'ānic words. These orthographical matters will be discussed here first (II). The bulk of the book (chs 12-14) is a series of (largely) unconnected suggestions for the emendation of individual verses in the Qur'ān based on the methods described in ch.3. This will also form the main part of the current review (III). The final parts of the work deal with broader issues, most famously that of the virgins of Paradise (here, section IV) and then the re-reading of Suras 108 and 96 (V). We shall conclude by discussing Luxenberg's meta-theory of the Qur'ān as a Christian lectionary (VI). In an Appendix, we have summarised some of the reviews of the book made over the years by prominent Arabists or Syriacists.

\section{Orthographic Syriacisms (chs. 7,10)}

\section{A Phonological Procedure: $\bar{e}$ in Classical Arabic as a marker of Syriac roots}

As an initial and general instance of the theory that a Syriac phonology underlies the Qur'ānic spellings of proper names, Luxenberg begins by discussing the examples غبريل and which, he claims must reflect the transcriptionally

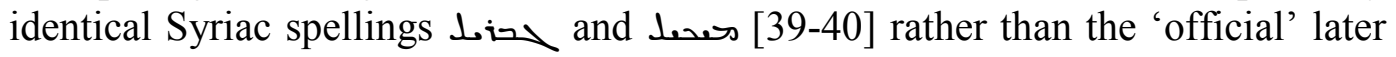

may mean by the expression simply the genetic relationship, rather as one might mean by GermanicEnglish or Gallo-French.

${ }^{3}$ A selection of reviews of the work are summarised in the Appendix and are from time to time noted in the paper. There is a more sustained response from a number of scholars available in the collection edited by C. Burgmer, Streit um den Koran (Verlag Hans Schiler: Berlin, 2004) but there is not space here to treat with these articles, some in favour, others opposed, and few of which actually interact with any of the detail of the book

${ }^{4}$ That of Phenix and Horn (Hugoye 6.1, 2003, http://syrcom.cua.edu/Hugoye), which, while being quite positive about the book, is very short and is descriptive rather than analytical. For Baasten, see Appendix.

Daniel King, 'A Christian Qur'ān? A Study in the Syriac background to the language of the Qur'ān as presented in the work of Christoph Luxenberg' in: Journal for Late Antique Religion and Culture 3 (2009) 44-71; ISSN: 1754-517X; Website: http://www.cardiff.ac.uk/clarc/jlarc 
Arabic pronunciations, Mīkāl and Ğibrìl. This explanation, however, is defective in a way we shall often meet with, namely that the Syriac evidence does not really support the weight of the argument, for neither of these are in fact the regular Syriac spellings of the names in question, which are דבתمـ, the shortened spelling may anyway be secondary to the Arabic usage. ${ }^{5}$ So with these two examples we are left with a definite problem - why, if the Qur'ānic spellings are taken from Syriac, were the alaphs systematically ignored?

The more pervasive and important theory used by Luxenberg, however, within this broad heading of phonological Syriacisms is the notion that, because some Arabic words may have ended with $\bar{e}$ by the process known as 'imāla, these may reflect the $\bar{e}$ of the Syriac emphatic masculine plural. Once he believes that he has established that this ending might be orthographically represented by final $\varsigma, 1$, or - (with or without the dots), the route is open to him to find a Syriac root in any such Arabic word.

For instance [44] مثلا (usually matala ${ }^{n}$ ) represents rather mathlē (i.e. Syriac $\left.\sim \sigma_{i \rightarrow s}\right)$ and thereby need not be interpreted as an external (adverbial) accusative, but rather becomes the grammatical subject of the sentence (Sura 11.24,39.29). This particular argument has been criticised by Corriente and de Blois on the basis that the resulting Arabic is not grammatically correct (the verb should now be singular), and by Stewart on the basis that the unemended text is unproblematic, for which he adduces parallels. ${ }^{6}$ The latter seems to be true of the next examples as well, in which سجدا (usually taken as an internal plural suğğad ${ }^{a n}$ ) is linked with r. Qur'ān was transmitted only in written form, since the original pronunciation $s \bar{a} \breve{g} d \bar{e}$, graphically represented as سجدا was later interpreted as representing suğğad ${ }^{a n}$. This is a point to which we shall return. Again, however, it has been observed that this particular form is actually attested in the Qur'ān, and is always to be expected in these contexts. ${ }^{7}$ Such a criticism raises a general issue of method which is so often the bugbear of textual criticism, namely the subjective question of whether a given text stands in need of emendation or not. Such a judgment can vary widely depending on the particular views of the critic concerned on such questions as what constitutes a linguistic difficulty, what constitutes a stylistic oddity, when does a lectio difficilior become a corruption in need of a solution?

\footnotetext{
${ }^{5}$ According to R. Payne Smith, ed., Thesaurus Syriacus (Oxford, 1879-1901), repr. Gorgias Press, 2007 [ henceforth Thes.], sech is found only Bar Hebraeus (Chronicle, ed. Bruns/Kirsch, 526,3, Chr.Eccl., ed. Abbeloos/Lamy, 727,14.23). Lin similarly is found only in Bar Hebraeus, who is simply transliterating into Syriac this personal name as it was pronounced in the Arabic of his day (the Gabriel referred to is a contemporary individual, and not the archangel).

${ }^{6}$ Corriente, On a Proposal, 311; De Blois, Review, 93-4; Stewart, Notes, 237-238, a point also made by Hopkins, Review, 378 although the latter does not show what is wrong with the reasoning as such.

${ }^{7}$ Stewart, Notes, 238.

Daniel King, 'A Christian Qur'ān? A Study in the Syriac background to the language of the Qur'ān as presented in the work of Christoph Luxenberg' in: Journal for Late Antique Religion and Culture 3 (2009) 44-71; ISSN: 1754-517X; Website: http://www.cardiff.ac.uk/clarc/jlarc
} 
Luxenberg is perhaps at his strongest when there is some corroboration for his readings already in the Arabic lexicographical tradition. Such is the case, for example, with الحوايا (6.146) [45-6], which Tabarī interpreted to mean innards, a meaning that makes sense as a mis-transcription of a Syriac meaning). The Lisān actually has this word as such: جو جوة which seem to be the masc./fem. forms but alternatively reflect the Syriac absolute and emphatic states ( $/ \mathrm{N} / \mathrm{N}$ ), although ta marbuta is being used as the mater lectionis for a final $\bar{a}$, more in line with Palestinian Aramaic than classical Syriac. ${ }^{8}$

This leads Luxenberg to a more generalised comment about the frequent use of $ت$ rather than $a$ in the construct state of fem nouns. His explanation is that the use of $ت$ in such cases is an orthographic Aramaism, such that جنت عدن need not be explained as a plural form but rather as the equivalent of غنة عدن , since both are Arabic transformations of the Syriac orthography 2 . forms such as the apparently feminine الخليفة can be explained as Syriac emphatic (i.e. definite) forms, where $\bullet$ represented $\kappa$ as mater lectionis, and only later received the pointing which turned it into the so-called ta marbuta. ${ }^{9}$ There are various other such anomalous 'feminines' given, such as داهية, علامة, طاغية. It should be noted, from the Syriac side, that the passive participle for radu (supposedly = never means anything remotely like substitute, deputy, even though the root meaning may permit such a meaning in theory. Furthermore, were this Syriac word to become an Arabic one, the result would be حليفة rather than 10

The most important result which bases itself upon this particular theory is the new explanations provided by Luxenberg of the Qur'annic forms of the names for Jesus and Moses [41-3]. According to Luxenberg, the name of Jesus عيسى is best explained on the basis of its similarity to Jesse مrك, (with the final $ى$ as ay), given the East Syrian tendency for initial 'Ayin to disappear into initial glottal stop (the equivalence of 'Ayin and initial glottal stop before a vowel is remarked upon in connection both with Mandaean and with East Syriac). The two names may thus have been confused.

The expression ابرهيم حنيفا (Ibrahīm the Hanīf) appears often in the Qur'ān in this (supposedly) accusative form. Again, taking the accusative ending and reading a Syriac emphatic, Luxenberg explains [55-7] the Qur'ānic form as a set epithet

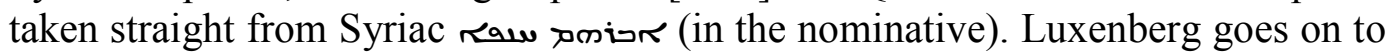
suggest more radically that the whole expression, "Abraham the Hanif, and he was not one of the idolaters," (2.135 etc.) should be reckoned as Syriac, with the conjunction taken as adversative, hence "Abraham was a heathen but he was not one of the idolaters." This now becomes an unexceptional and understandable

\footnotetext{
${ }^{8}$ That Syriacisms might in fact underlie forms with final ta marbuta is theoretically accepted by Corriente, On a Proposal, 311-12, though not in all the cases in which Luxenberg applies it.

${ }^{9}$ According to this interpretation, the ta marbuta can represent either Syriac $\bar{a}$ or $\bar{e}$, hence

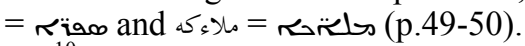

${ }^{10}$ See De Blois, Review, 94 . Of course, a simple re-pointing, such as is used often enough elsewhere, would quickly solve this particular problem!
}

Daniel King, 'A Christian Qur'ān? A Study in the Syriac background to the language of the Qur'ān as presented in the work of Christoph Luxenberg' in: Journal for Late Antique Religion and Culture 3 (2009) 44-71; ISSN: 1754-517X; Website: http://www.cardiff.ac.uk/clarc/jlarc 
piece of Christian or Jewish exegesis. This important argument has received cautious support as solving a series of grammatical conundra. ${ }^{11}$

The use of singular accusative nouns after the numbers 12-99 is considered by Luxenberg [58] as another oddity of Qur'ānic grammar in need of a simpler explanation, and this is found again in the suggestion that such nouns are not accusative singulars but original Syriac emphatic plurals.

Just as there was an 'imāla of $\bar{a}$ to $\bar{e}$, there was also a well-attested one of $\bar{a}$ to $\bar{o}$, which Luxenberg connects to the Syriac nomen agentis formation pā'ōlā (Nöldeke, Kurzgefasste Syrische Grammatik §107). This apparently explains a few more anomalous plural forms, such as قسورة (74.51). Traditionally, and without any grounds, interpreted as lion, this word can be found in Syriac (مهi) with the meaning decrepit ass, which fits the context rather better. Whether, as Luxenberg suggests, the Arabic actually retains the original form better because it conforms to the pā'ōlā formation is doubtful, but the correct lexical root has surely been found. ${ }^{12}$

\section{An Orthographic Procedure:s for $\bar{a}$}

Chapter 10 is an extended exercise on re-reading certain Qur'ānic words and expressions according to the theory that $\mathrm{s}$ can often represent $\bar{a}$ rather than $y$ and that, in a defective text, this could in fact apply to any form of the tooth, wherever the point might have been placed by the traditions of secondary exegesis. While much of this theory is based on the work of Diem, ${ }^{13}$ what is new in Luxenberg's application of them is the many new Syriacisms thus supposedly discovered.

The foundation for this orthographic theory lies in the derivation of the very word قران / قرعان from Syriac a derivation originally suggested by Nöldeke and which Western scholarship has generally accepted. ${ }^{14}$ The very idea of 'reading', after all, is likely to have been of non-Arabic origin in Muhammad's day and the Qur'ān readily took the form of the word for a lectionary from Christian and/or Jewish circles.

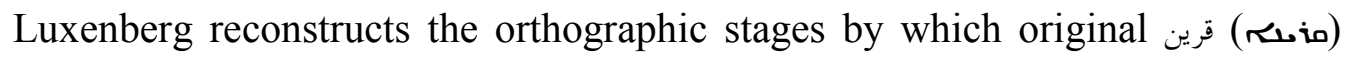
became first قرن , قران a قرءان and finally. Perhaps the theory's principle problem is that the first spelling قرين is not actually attested anywhere and is assumed by

\footnotetext{
${ }^{11}$ Stewart, Notes, 238-240. It is anyway fairly certain that the term حنيفة is related to the (Christian) Syriac naw - what is at issue is how the Arabic meaning can be derived. For a recent suggestion,

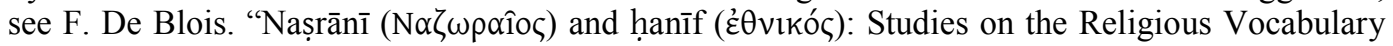
of Christianity and of Islam." Bulletin of the School of Oriental and African Studies 65 (2002): 1-30.

12 Jeffery, Vocabulary, 35-6 already strongly doubted its Arabic origin. Corriente, however, has an alternative solution in the Persian (Corriente, On a Proposal, 311).

${ }^{13}$ W. Diem, "Untersuchungen zur frühen Geschichte der arabischen Orthographie I. Die Schreibung der Vokale." Orientalia 48 (1979): 207-257; "II. Die Schreibung der Konsonanten.” Orientalia 49 (1980): 67-106; “III. Endungen und Endschreibungen.” Orientalia 50 (1981): 332-383.

${ }^{14}$ See below, n62. 
Luxenberg to be probable on the basis of the Syriac spelling. What needs to be shown, rather, is that this (original) spelling, without points, was misunderstood as qurān rather than as qurīn. ${ }^{15}$ As before, this theory entails another, viz. that at the time of the fixing of the text, there was no longer an oral tradition of pronunciation, hence the misunderstanding of some of the spellings.

The proof of the theory, Luxenberg claims to be evident in the examples of better readings that he finds by being free to interpret every tooth as a potential $\bar{a}$. For example:

1) إذاك (41.47) should be read as (therefore, = Syr wan, haydēk). Again, it should be noted that, although Luxenberg adduces a Syriac parallel for the word on the basis of his meta-theory, there is no need for such an Ur-text here. His emendation is a purely inner Arabic one. ${ }^{16}$ This mixing-up of different types of emendations is typical of the work as a whole and will be discussed further below.

2) عال (68.13) should be read arrogant), which is found elsewhere in the Qur'ān. This verse is further explained by a misreading of original رنيم as which is nonsensical.

3) 3 (18.9) is an old crux. Various commentators give various meanings, the most common being 'inscription' or 'writing'. The context, however, suggests something from the root رقد (to sleep) since the word occurs in the introductory رقاد on the basis of the theory here being used. However, this is the sort of area in which Luxenberg's lack of attention to other methods of solving exegetical difficulties lets him down. For source and literary critical investigations have now shown that the original 'makes complete narrative sense'. ${ }^{17}$. While the Arabic root (writing) should thus be retained, its form is still an anomaly, which Griffith suggests might be explained as a Syriacism of sorts, understandable in the light of a context in which Arabic-speaking Christians with Syriac backgrounds may have translated the story within their own religious milieu before it was taken, in unchanged form, into the Qur'ān. ${ }^{18}$ To this extent, although Luxenberg's emendation (and that of Bellamy) ${ }^{19}$ are probably unnecessary, it is still in the Syriac background that a solution is to be found, both in terms of the literary context and the grammatical forms of the Qur'ānic terms.

It is typical of Luxenberg's haphazard method that it is in this section that he introduces us, in passing, to a quite different aspect of his theory, namely the hypothesis of a Garshuni original underlying the Arabic text. Such a stage in the transmission allows him yet more flexibility with the emendation of letters. Thus

\footnotetext{
${ }^{15}$ There is some evidence from a Qur'ān ms, Paris Ar.328(a) - see Luxenberg, 73 n93.

${ }^{16}$ Stewart, Notes, 241-242.

${ }^{17}$ Griffith, Christian Lore and the Arabic Qur'ān, 125-127.

18 Ibid.

19 James A. Bellamy, "Al-Raqīm or al-Ruqūd? A note on Sūrah 18:9." Journal of the Asiatic Oriental Society 111 (1991): 115-17. 


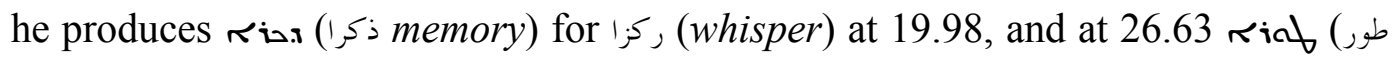
mountain) for طود. We shall discuss this aspect of the theory further below. In the same connection, we are introduced to the scribal habits of the Kufic Samarkand $\mathrm{ms}$, which include confusion of, and $\mathrm{s}$. This observation is so isolated as to be of little use here. What is needed is a full study of the scribal habits of the early Qur'ānic mss to assess what emendations are possible or likely. Such a study Luxenberg does not provide.

4) التورية (i.e. Torah). Luxenberg argues here for a Syriac rather than a Hebrew loan. Rhian explains the ending, and the ' $t$ ' at the start is on the basis of parallel examples, e.g. ה הior , He claims now to have actually found the term Yoraytha in Mandaic, thus proving that the should be read as ي. The mistaken reading : resulted from knowledge of the Jewish word among those responsible for the pointing, but this cannot have been the original pronunciation, which must therefore have been Yawrìya.

Again, we have an excursus within this section on the spelling of and ياجوج

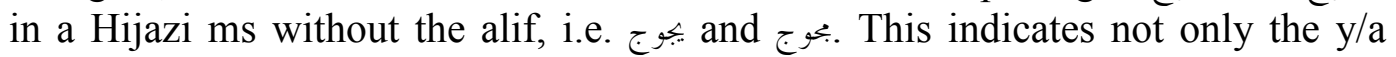
shift (from Syriac التورية but also the fact that alif can be used as mater lectionis for short $a$.

5) ابرهيم should be read again as mater lectionis for $\bar{a}$. The original

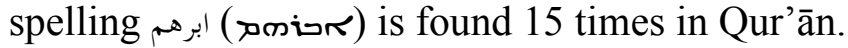

6) مزي traditional reading. Luxenberg's emended reading, partially in line with what one ancient commentator already suggested, is مرجية (R), refreshing fruits). This is probably an example of Luxenberg's poor use of Syriac lexicographical tools and his preparedness to accept any meaning found in the lexica which suits his purpose. We shall discuss this in greater detail later.

7) In براءة (9.1), the I should be read as يرية (Heb. brît, covenant).

These anomalous spellings, in which $\bar{a}$ is represented orthographically by any tooth, Luxenberg concludes [99], should not (as in Nöldeke) be treated as examples of 'imāla, but as an orthographic method of reproducing $\bar{a}$ in the early stages of Qur'ānic writing, which was forgotten by the later stages when oral tradition had been left behind. The whole theory presupposes a period in which the Qur'ānic text was preserved only in a written form, the pronunciation largely forgotten, and then a later period of Islamising exegesis. As always, Luxenberg keeps within his remit of purely textual considerations and arguments and unfortunately makes no attempt at an historical reconstruction of such a process of transmission. However, there have been those who have argued along similar lines and there has been some recent corroboration of this view. ${ }^{20}$ One reviewer has even suggested that this orthographical theory might be "one of [his] tangible contributions." 21

\footnotetext{
${ }^{20}$ Donner, Quranic Furqān.

${ }^{21}$ Stewart, Notes, 240.
} 


\section{The application of the method to individual verses of the Qur'ān (Chs 12-14)}

Having explored some of the implications of Luxenberg's theory with regard simply to phonology and orthography, we move on now to a more systematic appraisal of the method that Luxenberg uses to find his emendations and readings.

In chapter 3, a list of possible approaches to a corrupt reading are laid down [23-9]. These will guide the textual critic through the process of conjecturally emending the Qur'ānic text in line with the meta-theory of the Syriac Grundlage. These approaches are as follows:

A - The commentary of Tabarī should be checked for alternative interpretations.

B - The Arabic lexica should similarly be checked, esp. the Lisān al-'arab.

$\mathrm{C}$ - If the Arabic root appears nonsensical, the Syriac lexica should be checked for meanings of homonymous roots which better fit the context.

$\mathrm{D}$ - The diacritical points should be rearranged within the Arabic word to produce a better sense.

$\mathrm{E}$ - A combination of C and D, in which a Syriac root might be located beneath the Arabic word once the diacritics have been rearranged.

F - Possible Syriacisms and loan translations should be detected by retrotranslation.

$\mathrm{G}$ - The East Syrian lexical tradition should then be explored in the hope of finding old (and lost) meanings of Arabic words (this is another form of item F). The tradition is generally followed via the lexica of Bar 'Alī and Bar Bahlūl and in Mannā's Vocabulaire Chaldéen-Arabe.

$\mathrm{H}$ - The assumption of a Garshuni stage in the written transmission of the text will lead to further possibilities for emendation of individual letters.

A couple of brief comments are in order before we explore some of the specific applications of these principles. Firstly, options A and B are rarely used, and even more rarely trusted. More often, it is the errors in this Arabic exegetical tradition that are 'exposed' by Luxenberg's readings. Second, Luxenberg's use of the 'East Syrian lexical tradition' is somewhat haphazard and random, as will be seen in much of what follows - this places a significant question mark over item G. Furthermore, items $\mathrm{D}, \mathrm{E}$, and $\mathrm{H}$ are all based upon a series of assumptions about the possible scribal errors that might have occurred during a process of written transmission. To carry weight, these errors need to be shown to be possible according to a full study of the scribal habits of the early mss. Only on this basis can such emendations gain any security.

The observations that here follow are responses to the various comments made by Luxenberg. Because the latter is not in any way systematic and uses whichever of the above-mentioned eight principles are needed in any particular case (and often a combination of more than one of them), the responses to them are necessarily equally unsystematic. However, I have for the most part indicated which of the methods (A-H) seems to be used at any one time. Although these 
observations and comments are selective, it is hoped that they cover a broad range of Luxenberg's proposals, sufficient to make an assessment of the theory in toto.

A number of emendations are made to 19.24 [127-135]:

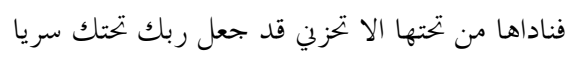

But the one that was below her called to her, 'Nay, do not sorrow; see, thy Lord has set below thee a rivulet ${ }^{2}{ }^{2}$

First of all, Luxenberg suggests that really means delivery (in the sense of a birth), since

a) ; can be read for : (D),

b) two medieval Arabic commentators refer to تحت as meaning womb in Nabataean (though this is not otherwise confirmed) (C),

c) the Syriac Thesaurus gives to descend from (in the sense of to have $\mathrm{x}$ as an ancestor/parent) as one rather obscure possible meaning of the verbal root hew $(\mathrm{C}) .^{23}$

He then posits a 'corresponding' Syriac word Rhw, which he thinks might mean delivery, foetus, although there is no such word extant in Syriac at all. ${ }^{24} \mathrm{He}$ does find some parallels in the Lisān, but these attest the meaning descent, birth rather than anything like delivery. As even Arthur Jeffery pointed out, the Arabic word is anyway hardly an obscurity at all since the reading under her is perfectly acceptable in all Semitic languages. ${ }^{25}$ It therefore does not really pass point A in Luxenberg's working method. $^{26}$

Having made such a conjectural emendation, Luxenberg has then to explain why the Qur'ān should use this hapax legomenon here, to which he responds [134] that it must be because the Qur'ān is trying to make Jesus' birth out to be special and different, a descent from above, which is, of course, exactly what the Syriac word does mean, but the feminine suffix (it is 'under her' or, if one prefers, ' 'her descent') excludes the possibility that Jesus' heavenly descent is actually in view here. The connection between the (supposed) literal meaning of giving birth with this metaphorical one of heavenly descent is arbitrary. The further argument from the Hebrew root נפל is irrelevant and adds nothing to the argument.

Continuing on the same verse, Luxenberg makes من (>) mean immediately after rather than from on the grounds that this preposition can have a temporal sense in Syriac. It can indeed have a temporal sense, but meaning from that point on, not immediately following, as Luxenberg wants to have it! He also wants شري mean not rivulet, as traditionally understood (which is problematic) but rather

\footnotetext{
${ }^{22}$ All translations provided are those of A. J. Arberry (Oxford, 1998).

${ }^{23}$ Thes., 2344.

${ }^{24}$ In fact, the closest is $r$ wu, meaning a vestment, something that descends (i.e. drapes) from the body! He actually admits this fact at $\mathrm{n} 180$.

${ }^{25}$ Jeffery, Vocabulary, 32-3.

${ }^{26}$ Paret's uncertainty as to the meaning [135] is not due to any linguistic obscurity as such, but is rather merely a query over interpretation. 
legitimate, based on a meaning he assigns to $\boldsymbol{\sim}_{\mathrm{ir}}$. This is equally tendentious from a semantic point of view, for there really is no such meaning in Syriac. He quotes Thes as giving absolvens, solvit, liberavit, but these mean to release, here in the ecclesiastical sense of to release from excommunication. Nowhere in the Syriac Thesaurus is the meaning legitimate suggested. He finds some slightly better parallels in Mannā's dictionary, but this cannot be taken as in any way authoritative for Late Antique meanings. It is clear that his reasoning is based on the meanings he expects from the context, given his previous argument about rather than on the likely roots involved.

$\sim_{\text {iz }}$ is then located in a couple of other verses elsewhere in the Qur'ān in one of those horizontal moves that makes the book hard to read as such. ${ }^{27}$ So, for in-

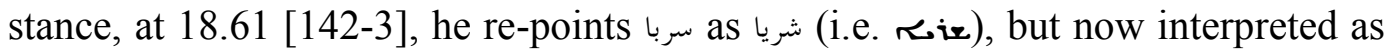
free, which is much more reasonable and fits the context quite well. Again at 78.20 [144-50] the similar سراب (mirage) is read as (things dissolved), while at the same time سيرت is read as deriving from itro (in fact as an internal passive of the root, corresponding to rithors, to be destroyed). This apparently makes better sense of 78.20, although the translators do not generally find the verse to be especially obscure.

Within this section is a brief discussion [144-7] of some related verses about the destruction of mountains at the last Judgment. In ينسفها is related to 20.105 turn to dust), which is a good reference, though the resultant meaning is not far from what the Arabic lexica have anyway. 69.14 provides an example of a retrotranslation (F): looking for a contextually appropriate translation for حم (usu. carry) Luxenberg finds it via عمل, which can mean both to carry and to remove, destroy. The meta-theory underlying this reading would thus be that of a translation technique in which words in the source language were assigned equivalents in the target language on the basis of the most common meaning of the former and that that same equivalent was used even when the intended meaning was somewhat different, on the assumption that 'equivalent' words must encompass identical semantic ranges. Such procedures were actually quite common in Late Antiquity and are well attested. ${ }^{28}$

The same procedure $(\mathrm{F})$ is used again to emend 13.31 [150-51]. Again, the variety of possible Syriac meanings provides the one wanted in the Qur'ānic context, here قطع which, following Luxenberg, should be considered equal to Ris, which can mean to split open:, "thus in countless cases the actual and precise meaning of an Arabic expression that does not harmonize perfectly with the

\footnotetext{
${ }^{27}$ The fact that the book represents a rather disjointed series of thoughts on different readings should not as such be held against the author, however. It is a procedure not unknown to some of the great classical scholars of the past. Each reading still needs to be assessed on its own merits.

${ }^{28}$ The best well know examples from the realm of Graeco-Syriac translations was the use of Syriac rusar (usu. glory) to represent Greek $\delta$ ó $\xi \alpha$ even when the latter had the sense of opinion rather than glory.

Daniel King, 'A Christian Qur'ān? A Study in the Syriac background to the language of the Qur'ān as presented in the work of Christoph Luxenberg' in: Journal for Late Antique Religion and Culture 3 (2009) 44-71; ISSN: 1754-517X; Website: http://www.cardiff.ac.uk/clarc/jlarc
} 
Qur'ānic context can usually be established by way of the semantics of the lexically equivalent Syro-Aramaic expression."

So again نغادر at 18.47 [151-7] cannot be to abandon (most translations give meanings such as to leave to suit the context) but is a retro-translation of which can mean to overlook (Mannā). This is an extreme example of the arbitrariness of the method, for out of a large variety of meanings in a late East Syrian/Arabic dictionary (Mannā), he has chosen (via a postulated Syriac equivalent) one which he thinks might fit the context. Given that there are Syriacisms aplenty in the Qur'ān, such a method might occasionally produce a good reading, but many more times it will make transparent only the exegetical proclivities of the critic and is nothing more than a function of the very wide semantic range that becomes available to him through the various dictionaries and other sources which he follows.

The same verse also has an example rather of a pointing error (D), requiring emendation of a quite different sort. For باريزة (?moved forward), what we should read is تاريزة (not an Arabic root, by means of method C the Syriac rLid, ripped open, is used instead).

A few more readings from this part of the book:

At 37.78-9 [157-60 تركنا Such to be read as to simple case of re-pointing (D) is not only plausible on its own, but is actually supported by the fact that the new reading turns up later in the same Sura (37.113). ${ }^{29}$ On the other hand, that should be read as a dual on account of its being a transliteration of حلمين is hard to fathom - for the latter is a regular plural ${ }^{30}$ which is how the translators of the Qur'ān have also taken it. One cannot see how the Arabic dual could have been originally 'intended' here on the basis of a transcription.

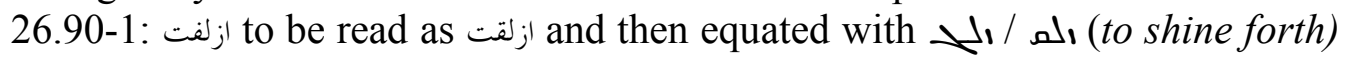
[E]. The Lisān even knows this root meaning, which is not the same as the normal Arabic one [B]. بزرت (26.91) has already been clarified before (18.47) as related to iid, thus providing a good contextualised meaning to the whole sentence.

The root اليز لقونك in they cause you to stumble). The Syriac root with the sense of to strike down should be accepted [E] on the basis also that the meaning is attested in Tabarī [A]. However, alternatively (he says) one could discern וحم here via a Garshuni error $[\mathrm{H}]$ in which $ح$ has been misread as $\lrcorner$ (a reasonably common Syriac scribal error), hence $J$ in the normal Arabic script. The regular Arabic cognate of صحق iحم, to strike down (with lightning). It would appear that this alternative reading is one which Luxenberg has added to the later editions of the book in the light of his article about the Garshuni Vorlage. ${ }^{31}$ If it were accepted as a better explanation, the type

${ }^{29}$ Stewart, Notes, 244.

${ }^{30}$ There is no dual number in Syriac (Nöldeke $§ 70$ ).

${ }^{31}$ C. Luxenberg, "Relikte syro-aramäischer Buchstaben in frühen Korankodizes im higazi- and kufi- Duktus." In K.-H. Ohlig, ed., Der frühe Islam: Eine historisch-kritische Rekonstruktion anhand zeitgenössischer Quellen (Berlin, 2007), 377-414.

Daniel King, 'A Christian Qur'ān? A Study in the Syriac background to the language of the Qur'ān as presented in the work of Christoph Luxenberg' in: Journal for Late Antique Religion and Culture 3 (2009) 44-71; ISSN: 1754-517X; Website: http://www.cardiff.ac.uk/clarc/jlarc 
of argument represented in the first alternative [E] becomes immediately rather weaker.

\section{The theory of the o of the apodosis}

A large part of the rest of chapter 12 [166-213] is taken up with the possibility that , may mark the start of an apodosis in Qur'ānic Arabic. This theory then leads to a series of readings which involve many other methods and applications of the principles set out above.

The theory regarding the apodosis marker is first mooted [154] in connection with 18.47 in which the protasis of the temporal clause appears to be without any apodosis. Luxenberg then suggests that the , before حشرفم marks the expected apodosis. This takes us back to the question of whether a a can function as an apodosis marker in Syriac in the way that it so frequently does in classical Hebrew. Luxenberg finds one example in the Syriac Peshitta (Gen 39.10) of just such a Hebraism, ${ }^{32}$ though he also rightly notes that in the vast majority of cases, the Syriac does not translate the conjunction. The two reasons given [156] for associating this (supposedly) Syriac usage with our verse from the Qur'ân are both to do with tense patterns and are quite irrelevant to the issue, as also is Nöldeke's observation about Hebrew tense patterns. The latter concerns observed Biblical Hebrew usage (and is anyway quite superseded by a vast post-Nöldeke literature on the subject which, as too often, Luxenberg knows nothing of) and has nothing to do with Semitic languages per se. Nöldeke has made quite clear elsewhere (Grammar §339) that o does not mark apodoses in Syriac except in rare cases of Hebraisms in the Peshitta - it was not carried over thence into Syriac literature and to find such a construction here in Arabic is indeed a great leap of the imagination, and is certainly not proven by any evidence Luxenberg adduces. ${ }^{33}$ Nonetheless, he proceeds to explain a large number of Qur'ānic verses by reference to this particular theory, some of which will be mentioned below, although interspersed with many other unrelated types of emendation which are discussed in an ad hoc manner.

37.103-4

فلما أسلما وتله للجبين وندثنه ان يابرهيم

When they had surrendered, and he [Abraham] flung him [Isaac] upon his brow, we called unto him, 'Abraham'.

\footnotetext{
${ }^{32}$ Even here, Luxenberg misreads the Syriac, for in his example [154] the apodosis is the clause beginning $ه$ a not the clause beginning rama!

${ }^{33}$ See also E. Beck, "Die konditionale Periode in der Sprache Ephräms des Syrers." Oriens Christianus 64 (1980): 1-31. 
There are a number of issues and possible re-readings raised [166-77] for 37.103-4 within the story of the (near) sacrifice of Isaac, the first of which is the application of the above-mentioned theory, such that verse 104 becomes the apodosis to the time clause introduced in 103.

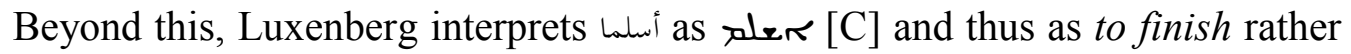
than the traditional to resign themselves (which makes little sense in the context). He claims this is supported by a known variant in the commentators, which suggests reading the Arabic verb as Type I rather than Type IV. However, the Pael and Aphel (i.e. Type II and Type IV) of علم actually fit his meaning more closely than does the P'al (Type I). Rather than a philological argument, the principal driving force behind this reading is the assumption that the Gen 22 version of the story is in the immediate background here. Hence when they were finished (making the preparations) makes more sense to him than the theologising when they had resigned/submitted (to God's command). Something similar happened

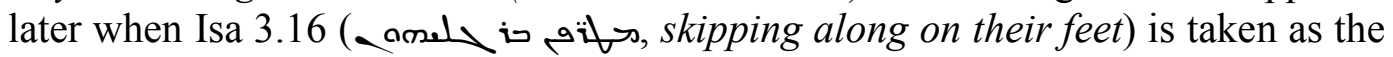
background to 24.31 (يضربن بارجلهن) [208], such that he can then posit פib as the background word always for ضرب بض (via the unvoiced Eastern pronunciation).

جبين, traditionally forehead, temple, is in fact of quite unknown origin. Although, Tabari gives a variety of possible etymologies, the derivation must be (between the eyebrows, i.e. the forehead, brow), since the word is never attested in normal Arabic other than as deriving from this verse [C]. However (following Luxenberg), even this is an error, as the root we are looking

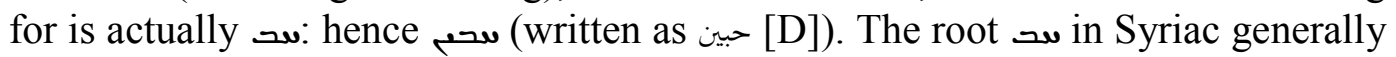
means to set on fire, and the participle that we have here means burning things, in the active, not the passive sense. Luxenberg then has a highly convoluted paragraph [174] in which he attempts to argue that this could mean firewood, though this is far from convincing, such a meaning never being attested in Syriac. One can see how tempting it is, however, in view of the fact that it fits the context so well (as in the case of ع noted above).

تر, traditionally to throw down is never attested as such except by the usual reverse lexicography (i.e. using post-Qur'ānic poets to attest the meaning, as in the Lisān). L finds $\sim \boldsymbol{r}[\mathrm{C}]$ and then forces this root to mean to bind in addition to the usual to hang by means of the ingenious equivalence of to hang on a cross and to bind to a cross!

Through the further move from $J$ to $\sqrt{ }$ [174-5] on the firewood becomes possible [F]. This fairly significant semantic shift is justified, after finding no grounds for it in either Arabic lexicography or in the Thesaurus, by a single reference to Mannā and 'a function documented by the Eastern Syriac lexicographers' for which no reference is provided. ${ }^{34}$

\footnotetext{
${ }^{34}$ The fact that the single example adduced from Mannā is found under his $25^{\text {th }}$ meaning of $\lrcorner$ gives a sense of just how many options Luxenberg has before him for finding new readings when delving the depths of such dictionaries.
}

Daniel King, 'A Christian Qur'ān? A Study in the Syriac background to the language of the Qur'ān as presented in the work of Christoph Luxenberg' in: Journal for Late Antique Religion and Culture 3 (2009) 44-71; ISSN: 1754-517X; Website: http://www.cardiff.ac.uk/clarc/jlarc 
Finally in this verse it is suggested that really refers back to a Syriac a $[\mathrm{F}]$. The further implication would be that the Qur'ānic usage of iأ to introduce direct speech is a calque on Syriac x. This is a major assertion and deserves a good deal more consideration than is offered here.

Once all these different readings within 37.103-4 have been added together, a wholly new understanding is produced, one which does, it must be admitted, make good sense and yet which is produced by so many leaps of the lexical imagination that one is left wondering whether one is not just being treated to an overall reading which is too convenient for the author's meta-narrative of Christian origins to be taken seriously on philological grounds. However, the new reading of this passage has received the approval of at least one major scholar of the Qur'ān, and should perhaps be given a further hearing. ${ }^{35}$

At 12.15 [177-82] is another example of , for an apodosis, which is indeed so far suggested by the context that one non-mainstream modern translator actually renders it in such a way. ${ }^{36}$

Further, rendering إجمع as to agree is based on Syr and and being cognate) and is thus a loan formation (F).

غيبت (bottom) =ححم (bosom, depth). Some derivations of this root in Syriac have the meaning of darkness (esp. حم حרז, which actually corresponds more closely with the Qur'ānic form here), which Luxenberg prefers. But there is no need to conjecture a pointing change to عيب since the Syriac ayin can equally well be either $\varepsilon$ or $\dot{\varepsilon}$.

At 18.79 [186-7] there is some confusion of method. He argues that أعيبها should be repointed as Form II of غاب (i.e. as أغيّها), to conceal rather than to damage. However, his move via Syriac ברב $[\mathrm{C}]$ is wholly unnecessary - he takes from Mannā's dictionary the meaning of to camouflage, whereas, as he has already admitted, the classical Syriac can only really mean to darken (as with clouds), which is not what is required in this context. For his purposes, however, the repointing [D] is quite sufficient.

The same happens again with regard to 21.87 [188-9] where مغضب (supposedly in a rage, although this is admitted by translators to be a problem) is read as (rebellious, disobedient), a meaning that much better fits the context of the story of Jonah. There is no need then to equate this with $\sim_{5}$. Such a move presupposes the theory of Syriac origins but does nothing to ground it since the Arabic root provides the reading he sought.

With 12.15 [189-90] we have another instance of a loan formation (F). For something like to place into the pit seems to be demanded, yet this does not come easily from the usual Arabic meanings. Only when we note that in general is used for to (to place) and that the latter can also have the sense of to place in a grave does the route to the meaning of the Qur'ānic expression become clearer.

\footnotetext{
${ }^{35}$ Reynolds, Introduction, 16-17.

${ }^{36}$ That of Richard Khalifa, to be found at www.submission.org. 
The same procedure again where 0 is taken to mean plot rather than affair on the grounds that (its Syriac cognate root) is synonymous with $\mathrm{Il}_{\mathrm{s}}$ and that the noun derived from the latter, rabs can sometimes mean plot! I, for one, cannot find this meaning anywhere in the Thesarus, ${ }^{37}$ but even if it were an acceptable meaning for rabs, the semantic leaps here made are extreme. To say that "in order to do justice to each of the meanings of the Qur'ānic terms....and their derivatives, the different semantic contents of the Syro-Aramaic synonyms...must absolutely be taken into account" [190] allows one, via a series of leaps from one synonym to the next within very wide semantic fields, to almost any interpretation one seeks, especially when we are dealing with such fundamental and common roots as these.

\subsection{9 [191-7]}

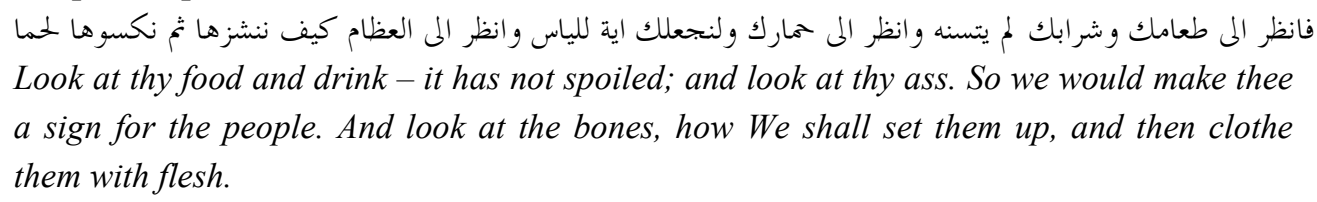

Here Luxenberg finds not only a further instance of , for the apodosis, but also a series of other alternative readings which warrant closer investigation.

1. Firstly, another poor instance of method [C]. طعام (food) he relates to rave, for which Luxenberg finds (in Thes) the meaning mens (which he translates into English as understanding, but what is meant is rather mens with the meaning good sense, good taste, as is evident from the examples Payne-Smith gives) and for the cognate noun rsos b he finds qualitas, providing him with the translation condition that he seeks. However, a closer look at the evidence for this Syriac meaning will cause him difficulties. For Payne Smith's principal reference is to the Syriac version of Cyril of Alexandria's Commentary on Luke, in which a gloss

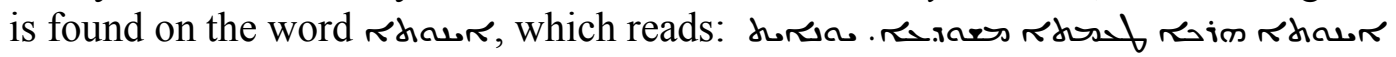

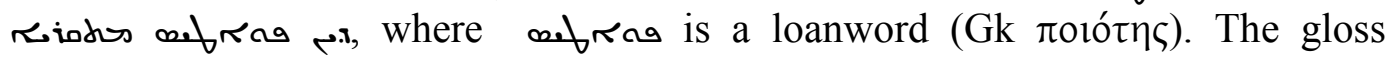
(written probably by the translator himself (keeping in mind that this is a translation from the Greek) tells us that the word rhow in the main text is a

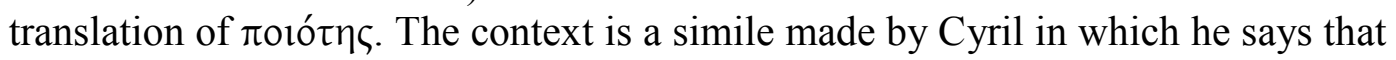
when we dip bread in wine or oil, the bread takes on the character or quality

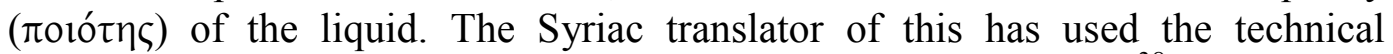

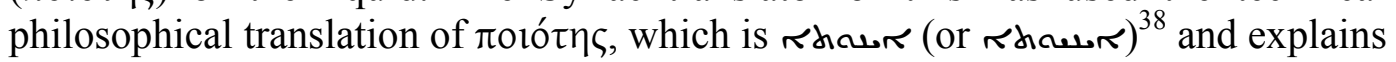
this (to most readers unfamiliar) term by adding in the margin, "Quality in this

\footnotetext{
${ }^{37}$ Supposedly at II,2111, but this must be a mistake, for it is not there.

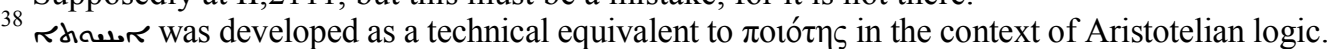
See H. Hugonnard-Roche, La Logique d'Aristote du grec au syriaque (Paris, 2004), 27. This translation value and its difficulties are actually discussed by the Syrian philosopher Jacob of Edessa, in his Letter on Orthography (G. Phillips, ed., A Letter by Mar Jacob, Bishop of Edessa, on Syriac Orthography. London, 1869), 8.
} 


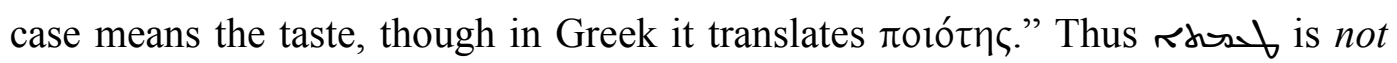
here being used to mean quality per se but simply explains this particular expression of Cyril, who is talking specifically about the transfer of taste from the wine or oil to the bread. rsos therefore here carries its everyday meaning of taste, not the abstract meaning of quality, condition which Luxenberg seeks for it.

If we look at the other examples adduced for this meaning in Thes., all of them taken from Ephrem, we see the same metaphor at work. In one place, taste as such is clearly in view (part is a sweet taste, and part a bitter one), ${ }^{39}$ and where he is talking about the two aspects of freewill (the desire to do and the desire not to do), Ephrem is hardly thinking of abstract qualities but rather of general varieties of

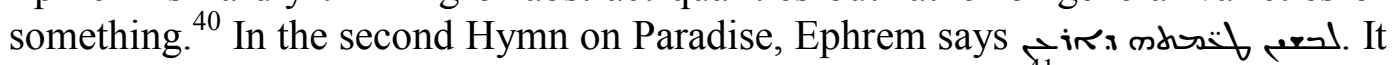
is because Assemani translated $r$ surb here as qualitates, ${ }_{11}$ that this reference then appeared in Thes. under this head. However, the much better idiomatic translation of Brock reads, 'since they put on the savors of our land', ${ }^{42}$ in which translation the metaphorical use of rhos $b$ as a taste becomes quite clear. This metaphor explains all the Ephremic references, and the Cyril of Alexandria reference has already been dealt with above. This should lay to rest the idea that either rascb or asw can really have meant condition or state, as Luxenberg would have it to suit his reinterpretation of the verse. His use of Mannā's dictionary is, as always, equally problematic.

2. شرابك, as Luxenberg points out, should be an approximate synonym or complement to the previous term. However, to make rair mean a state, condition, he again has to turn to Mannā. Ordinarily, the word simply means $a$ thing that pertains to [something]. Regarding the discussion on both these terms, it should be added that in the traditional form of this story of Abed Melek / Abimelech (which is found in the Jewish pseudepigraph Ethiopic [4] Baruch), ${ }^{43}$ when the protagonist wakes after his 100 year sleep, the freshness of his food is specifically mentioned as part of the miracle. It may well be that Luxenberg 'cannot see why God...points out to the man...that his food and drink have not gone bad' but the author of the original version of the story did say just that. Abed Melek realises that he has been asleep for many years precisely through the fact the figs are in season when they should not be. The miracle is thus precisely in the freshness of the food. Here, as elsewhere, then, the traditional understanding is not problematic.

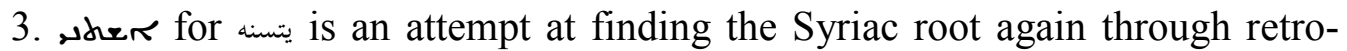
transliteration (a type of $[\mathrm{C}]$ ). While the traditional meaning of the Arabic (to alter

\footnotetext{
${ }^{39}$ J. J. Overbeck, S. Ephraemi Syri, Rabulae episcopi Edesseni, Balaei aliorumque opera selecta (Oxford, 1865), 36,7.

${ }^{40}$ Op. Cit., 35,12 .

${ }^{41}$ J.S. Assemani, ed., S. Patris nostri Ephraem syri opera omnia quae extant (Rome, 1737-43), III,567.

${ }^{42}$ S. Brock, Saint Ephrem, Hymns on Paradise (Crestwood, NY, 1990), 88.

43 S. E. Robinson, ed., in J. H. Charlesworth, Old Tetament Pseudepigrapha (London, 1985), II,419-21.
}

Daniel King, 'A Christian Qur'ān? A Study in the Syriac background to the language of the Qur'ān as presented in the work of Christoph Luxenberg' in: Journal for Late Antique Religion and Culture 3 (2009) 44-71; ISSN: 1754-517X; Website: http://www.cardiff.ac.uk/clarc/jlarc 
over the years, i.e. to go rotten) is a problematic reading, the solution depends on Luxenberg's understanding of the whole passage, as discussed above.

4. However, the simple emendation of كمار to tour perfection) [E], by repointing $\tau$ as fits the context well, produces good sense and solves what looks like an obvious corruption.

5. نشر is read for نشر. This is then explained as a loan translation of $\forall \cdot a$, because

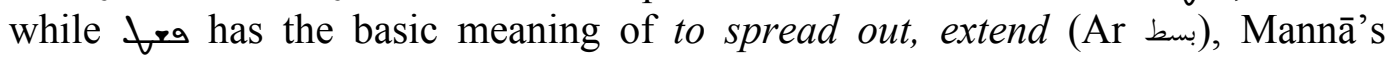
dictionary does once gloss it with نشر. He then trawls through the other glosses

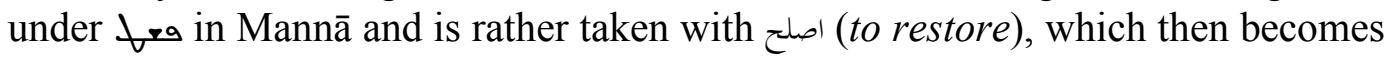
the new meaning for نشر. This is thus a combination of methods D and F. Using the basic meaning of the (already emended) Arabic he goes back into a possible Syriac equivalent, looks for other Arabic glosses on that Syriac root and finds one that he believes fits the context better. When using dictionaries of glosses such as Mannā's (or, for that matter, the East Syriac lexica of Bar Bahlūl and Bar 'Alī), such a two-stage method does open up a large number of permutations and possible results, such that whichever he picks on can appear arbitrary.

\subsection{6-7 [197-215]}

$$
\begin{aligned}
& \text { فلولا كان من القرون من قبلكم اولو بقية ينهون عن الفساد في الارض الا قليلا ممن ابجينا منهم واتبع الذين ظلموا ما }
\end{aligned}
$$

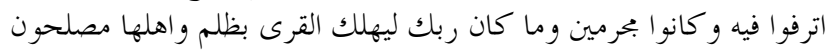

The discussion of this pair of verses again starts with the issue of reading $g$ as introducing an apodosis.

Readings based on obscure Syriac glosses are sometimes truly unnecessary e.g. rom as to remain [202, n268]. Readings such as this can only be made once his thesis of a Syriac substrate is established on firmer evidence, not as part of the proof for that theory. One of the work's most serious flaws is the fact that the theory is not proved separately from its application, and so readings such as this are proposed and asserted without further question.

The same method as we saw enacted upon نشز in the previous discussion is used again here with بقيه (F).This is retro-translated to id, which can have the meaning to be virtuous (Ar فضل, which has itself taken on the meaning of virtuous by means of this basic root) and hence he argues that this is what means. This reading works rather better than most because the traditional exegesis has already provided the meaning we seek, namely virtuous. To the Syriac speaker a connection between the rest and virtuous is ready to hand in the term io which comfortably (and without the semantic leaps sometimes used) covers both. A 
mistranslation does therefore seem to be in view here. ${ }^{44}$ The further meanings of بقيه which he later adduces [212-3], however, are wholly arbitrary and return to the bad ways of using dictionaries to produce almost any meaning that is desired.

is explained by an ingenious use of [C]. For again, the exegetes knew what was meant (to be dissolute, licentious, which meaning they accorded to the root (ترف). However, the Syriac word with this meaning again lies ready to hand, i.e. ri, from which the Ethpael from (in which the 。was originally mater lectionis for the final weak letter rather than the stem consonant which it has become in the modern Arabic root).

\section{Underlying Syriac Syntactical Structures}

In ch.13, Luxenberg moves on from dealing with individual words and takes a look rather at instances of basic grammatical structures in the Qur'ān that are modelled on Syriac grammar.

The chapter begins with a discussion of 19.23 [214-21] in which Luxenberg locaters a Syriac substrate on the grounds that Syriac grammar would better explain the unusual word order found there, in which the infinitive precedes rather than follows the verbal form which it reinforces. Nöldeke, §295-6, does indeed make clear that the order Infinitive-Finite Verb is the normal one in Syriac, though his more general observation that word order in Syriac is simply more flexible is less to the point.

Still in the same verse, he next deals [217-8] with endings on predicate adjectives and participles that appear masculine in Arabic but refer to feminine subjects by suggesting that they are in fact Syriac absolute feminines in $\approx$ which therefore look like masculines after being transcribed into Arabic without the : because the Syriac lacked the $h$ of the emphatic. It is important to note, as we have before, that this virtually presupposes the theory of the Syriac substrate and is too great a leap to use as evidence for that theory.

This is especially clear when he deals with the examples of 7.56 and 3.40, in both of which a feminine noun is followed by an (apparently) masculine predicate. Luxenberg explains this by the supposition (linked to that just noted) that the absolute feminine was read as an emphatic masculine and the $a$ was thus dropped from the latter as it always was when Syriac words went into Arabic. This is now a two-stage error, first the Syriac on has been transcribed directly into Arabic, and then a second confused scribe is supposed to have taken it as a masculine (since 'usually', he says, Syriac emphatic masculines had the $a$ removed before being rewritten in Arabic) and recast it as normal Arabic قريب. Again, if one knew for certain already that the Qur'ān was nothing but a translation of a Syriac text then such a process would be just about conceivable,

\footnotetext{
${ }^{44}$ Supported also by Corriente, On a Proposal, 310.

Daniel King, 'A Christian Qur'ān? A Study in the Syriac background to the language of the Qur'ān as presented in the work of Christoph Luxenberg' in: Journal for Late Antique Religion and Culture 3 (2009) 44-71; ISSN: 1754-517X; Website: http://www.cardiff.ac.uk/clarc/jlarc
} 
but it requires too many postulated intermediary stages to be taken as in any way proof that there ever was such a Syriac background in the way that he describes it.

16.79 [221-6]

الم يريا الى الطير مسخرت في جو السما ما يمسكهن الاالله

Have they not regarded the birds, that are subjected in the air of heaven? Naught holds them but God.

سخر has been taken as to serve, which matches the cognate iur. However, Luxenberg points out that it could equally well be based on the Shaphel of iur (rw) which would then mean to stay back, tarry, virtually synonymous with the يكسكهن which appears later in the verse, and which thus fits the context far better. This is surely an excellent emendation which makes good sense of a clearly problematic expression. The same root lies behind مواخر (16.14/35.12), i.e. it is the Aphel ptc of iur, and not an imagined Arabic word for ship. This error has turned up a number of times in Qur'ān (14.32, 17.66, 7.54, 16.12, 2.162, see p.225).

Every now and again Luxenberg seems to point specifically to an East Syrian milieu for his posited lexical background to the Arabic of the Qur'ān, and this example is one such place, for he suggests that the mutation of the $a u$ diphthong of iwa into the simple $a$ of (sahhara) is illustrative of a vowel-shift typical of East Syriac dialects. The difficulty is both in the detail and the wider picture, for the vowel-shift that he describes is from $a u$ to $\bar{a}$ not $a$ (also see Nöldeke $\S 49$, which does not mention this particular shift), and furthermore the historicolinguistic reconstruction required to make an East Syrian dialect the Hintergrund of the language of the Qur'ān would be even more radical than were a West Syrian dialect being proposed instead, since Mohammad is at least known to have travelled in Syria, but not in the regions of the Eastern dialects and if there was a Mischsprache in Mecca it would more likely be related to West Syrian forms than Eastern. Furthermore, it is very possible that the reason for his frequent 'discoveries' of East Syrian dialectal forms is more a function of the dictionaries he happens to depend upon.

The foreign background to صراط was well known already to Arthur Jeffery, who suggested that it was derived from Latin strata, having in mind the military road that passed up the Persian-Roman border, the strata diocletiana. ${ }^{45}$ Luxenberg [226-7] prefers rather to posit a Syriac background through the word rino (line), which does indeed provide the right meaning, although it is linguistically more difficult to defend than tifor since the loss of the first $\downarrow$ requires explanation. ${ }^{46}$ When, however, Luxenberg proceeds to suggest that even the Latin strata is itself a loan from $r$ ino he goes far beyond the evidence and reveals too

\footnotetext{
45 Jeffery, Vocabulary, 195-6.

${ }^{46}$ ti Syriac, e.g. in the Acts of the Seven Martyrs of Samosata (Thes., s.v.).

Daniel King, 'A Christian Qur'ān? A Study in the Syriac background to the language of the Qur'ān as presented in the work of Christoph Luxenberg' in: Journal for Late Antique Religion and Culture 3 (2009) 44-71; ISSN: 1754-517X; Website: http://www.cardiff.ac.uk/clarc/jlarc
} 
much of his ideology! Strata meaning something like path, as being a participle of sterno, was a common word already in early Latin literature which quite excludes any eastern influence. ${ }^{47}$ It was adopted into Greek as a loanword already in the fourth century. ${ }^{48}$

He compounds this particular error by extending the imagined pattern of Semitic $s$ to Latin $s t$ in the case of East Aramaic (camp,. which he links to Syr rdiu山, and from thence the Qur'ānic قصر, camp) to Latin castrum (camp). Firstly, rhis山 never means camp, only sometimes something like a battlement (only via Mannā does he even get close to what he seeks), but again by far the biggest problem for the idea is simply that one would have to project the Semitic term far into the unrecorded past for any influence upon Latin to have taken place. Luxenberg's unwillingness to consider historical contexts for his proposed linguistic observations makes him open to strong criticism especially in this case, and by extension elsewhere also. ${ }^{49}$

The historical context that he is lacking for an explanation of the wider theory he almost attempts to supply, without its significance being elucidated, via the discussion about the meaning of قريش [236-8], which the Lisān already suggested might mean gathered together. The latter he then takes as meaning a confederation (foederati), and goes on to suggest that the tribe of the Quraysh were actually the Christian Arab tribes allied to Byzantium. However, his derivation of this rather obscure Arabic meaning from Syriac مi is fanciful, as the latter is surely an Arabic loan. ${ }^{50}$ The idea that a large federation of semiChristianised Arabs may have been present in Mecca in the early sixth century of course provides Luxenberg with a route by which his Syriac Ur-text might have been contextualised in that area, but to ground this on an obscure etymology of قريش would be slim evidence indeed.

We have had so far very few examples of errors coming about through the mistranscription of a postulated Garshuni text [H]. Some examples are given [239-41] concerning Syriac $x$ and $;$ being misread by the Arabic copyist as Arabic 9. As he himself, admits, these readings (as with most of his readings) are based on what the context seems to demand rather than any known patterns of scribal errors in early Qur'ānic manuscripts.

The reading at 8.2 is a case in point. For to read the admittedly-problematic as Lux, to fear, requires a double error, first of type [H], in which a Garshuni text containing $x$ was mistranscribed into Arabic as , and secondly a mispointing later within the Arabic transmission of $\tau$ to $\tau .51$. The 'solution' in this case is found via

\footnotetext{
${ }^{47}$ Ennius, Frag. 311; Vergil, Aeneid 1.421; Lucretius, De Rerum Natura 6.1222; also Paulinus of Nola, Carmen 19,560.

${ }^{48}$ E.g. ps-Macarius, Hom. 3,2,1 (H. Berthold, ed., Makarios/Symeon Reden und Briefe. Berlin, 1973).

${ }^{49}$ We do not care even to discuss the fanciful etymologies proposed for English corsair and pirate, the classical etyma of which are fully documented [238]!

${ }^{50}$ Brockelmann, Lexicon Syriacum, s.v.

${ }^{51}$ The same procedure is then used also at 15.52,53,23.60, and at 11.70 for $i$ to $9 .$. 
the explanations already to be found in the exegetes rather than through any known process of scribal error, according to which some rather ignorant scribe, while in the midst of rewriting a Garshuni text in Arabic letters, might actually have imagined that a Syriac $\mathbf{r}$ in front of him was meant to become $g$.

Before we move on finally to the later chapters of the book, one final example of a good reading based on the Syriac meaning of the Qur'ānic word [C]. قيما (5.97), understood as مescovenant [54 n65], thereby revealing some sort of Syriac religious language in the background to the Qur'ānic language. The potential significance of the point, however, is not drawn out.

\section{Christianising the Qur'ān: The Virgins of Paradise (Ch 15) ${ }^{52}$}

Finally, we come to the one 'Syro-Aramaic reading' that has gained most notoriety since the book's first appearance, namely that حور عين means not virgins of paradise, as traditionally taken, but should be read rather as meaning white grapes.

It is important to note first of all that Luxenberg sets out the reasons why he believes the expression to be problematical and in need of either explanation or emendation:

1) The Qur'ān elsewhere speaks of the wives of believers joining the men in Paradise (43.70 etc.) and thus a contradiction is created which needs (sic!) a solution;

2) The term should not be a plural in Arabic (to consider it so is special pleading for Arabic grammar as a means of achieving the traditional exegesis.

3) Once 'virgins' is assumed as the denotation of the expression, then the fact of their eyes being white has to be explained away, such that Bell ends up translating it as dark-eyed. In Luxenberg's view, all this exegesis is clearly secondary and an emendation is thus called for.

4) More specifically, he also suggests that the 'error' came about through a further misreading, namely زوج (to marry) should be read rather as (to let rest) [D]. Once the former word was being read, its object had to be interpreted as something that would fit this meaning, hence the maidens.

The strangest aspect to Luxenberg's whole approach to this problem in particular (and it presumably applies to the whole thesis taken together) is found in the strange insistence that he is 'restoring' to the Qur' àn its 'original' meaning by making it agree with the Christian Bible in order to uphold the Qur'ān's own claim that it is in harmony with earlier Scriptures (e.g. 4.82, for the argument, see p.249-50, and again p.257). It is a strangely religious and ideological argument which, to be fair to the author, has not surfaced before this point. Here, however,

\footnotetext{
${ }^{52}$ For another response which proposes an alternative Syriac background, J. M. F. van Reeth, "Le vignoble du paradis et le chemin qui y mène. La these de C. Luxenberg et les sources du Coran." Arabica 53 (2006): 511-24. 
it clearly calls into question the whole philological project and makes it seem a theological one, almost as if Luxenberg were offering a post-modern reading of the Qur'ān in the cause of inter-religious dialogue! $!^{53}$

\section{The New Theory}

Luxenberg notes that while grapes are always mentioned in descriptions of earthly gardens in the Qur'ān, they are only once mentioned in connection with Paradise (whereas many other types of fruit are described as being in Paradise) - this might suggest that there is a gap to be explained or filled.

To be fair to the author, his real difficulty thus lies with the semantic content of these terms and not their Arabic forms which are perfectly acceptable per se. ${ }^{54}$

He then refers to earlier scholarship on the Syrian poet Ephrem's Hymns on Paradise, in which one scholar once thought he had found a pre-Islamic origin for the image of the virgins. Once this idea is correctly set to one side, however, and one accepts (as Luxenberg shows) that Ephrem speaks only of grapes, the reference matters not at all as far as the explanation of the Qur'annic term is concerned. This whole section [258-60] has nothing to do with the argument and truly deserves no more than a footnote.

Finally, we arrive at Luxenberg's philological explanation of what حور عين might really mean. He finds two Syriac equivalents [F], namely riaw, usually just white,

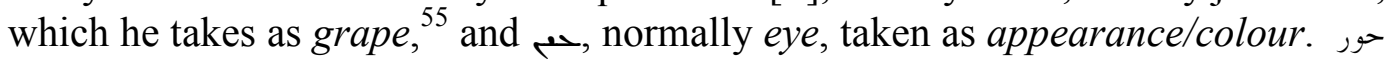
as being white in some sense is a reading accepted by all Qur'ān commentators, although as such it is undoubtedly a loan word. ${ }^{56}$ is a perfectly ordinary word which would not seem to stand in need of explanation, especially if both words are taken as plural (substantivised) adjectives, white [skinned], [wide] eyed [women]. Some ancient commentators (al-Azharī) have pointed out that حور only means women who are both white of body and white of eye. Indeed, a poetic description of heavenly beings as white should seem quite unremarkable in view of Christian depictions of the same (Revelation 3.4 etc.). In Syriac, a can certainly mean appearance, gleam, sparkle, colour. This is an idiom found in Classical Hebrew too (Leviticus 13.55, referring to the colour of diseased skin; Numbers 11.7, the colour of bdellium). The Syriac 2 is used in the Peshitta translation of Numbers 11.7 and Ephrem uses it to refer to the colour of a gem. In

${ }^{53}$ This is, of course, the point at which Luxenberg comes closest to the agenda of Karl-Heinz Ohlig, One or Three? : From the "Father of Jesus" to the Trinity (Frankfurt, 2002), together with the 'restoration' of a 'pristine' non-Nicene form of Christian doctrine from early Islam, but this much broader and equally controversial question cannot be further pursued here.

${ }_{54}^{54}$ Contra Stewart, Notes, 243.

55 The substantivised adjective can have this meaning in Syriac (P. de Lagarde, ed., Geoponicon in sermonem syriacum, 33,27) but is not at all common or used in a religious context.

${ }^{56}$ Jeffery, Vocabulary, 120. 
fact, however, the Syriac could have been brought even closer to the meaning he was looking for, since 2 can also refer to the bud of a vine..$^{57}$

The insurmountable methodological barrier remains, however, that Luxenberg has sought this meaning from the assumption that this is what he believes it should mean in context, rather than starting with a philological investigation into the roots of the words themselves. The procedure followed in this case by Arthur Jeffery is more rigorous and correct - he shows first, on the basis of examples from Arabic verse, that the expression does and can refer to beautiful maidens, and only then seeks the philological explanation for this, which of course wholly avoids the need to problematise عين.

Furthermore, the emendation requires many other re-readings in other verses, in which, he supposes, exegetical readings have been made on the basis of the traditional conception of the Hūris, the sum total thus being a loss of sense rather than sense gained. ${ }^{58}$ For instance, at 2.25 , the traditional reading pure wives must be read as species of pure [fruits], and الطرف in the expression قصرات الطرف [37.48-9] has to be read as based on 9 ib, to pick the grapes [D].

\section{Reinterpreting Whole Suras (Ch 17)}

In chapter 17, Luxenberg turns his attention to alternative reading not of individual verses but of whole Suras, of which he follows through two examples, Suras 108 [292-300] and Sura 96 [300-325]. ${ }^{59}$

In the first of these, it is only two words that are significantly re-read. ${ }^{60}$ First, is taken as its Syriac transliteration حموثر (minus the doubling of the d, which is then read with Rukkākhā), meaning constancy or perseverance, and بخ is re-

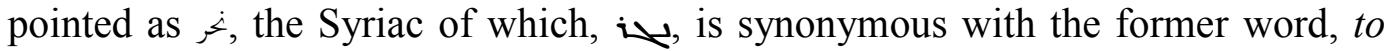
persevere, last. The result of this re-reading is that verses 1-2 become a pair of parallel synonymous expressions. As such the re-reading is not unappealing, especially as the two terms thus become synonymous and yield a neat parallelism. It deserves further consideration and research. ${ }^{61}$

Luxenberg, however, wholly lets the argument down with the explanation he then proceeds to give [300-1] in which he suggests that Sura 108 is a Syrian liturgical pronouncement in the manner of 1 Peter 5.8-9. One must point out, however, first that the Syriac version of these verses does not include any of the words he has proposed for the Sura (only in English, or German, do they appear superficially

\footnotetext{
${ }^{57}$ Thes., 2867.

${ }^{58}$ Stewart, Notes, 242-4.

${ }^{59}$ Other such studies have since appeared, e.g. the re-intepretation of Sura 97 (al-Qadr) as a Christmas liturgy, Luxenberg, Weihnachten im Koran (Sura 97).

${ }^{60}$ The two words that he re-reads in the final verse, شائكك and الابتر, although he 'finds' Syriac roots for them, are left meaning much as they traditionally have done.

${ }^{61}$ It is considered 'plausible' by the usually sceptical Corriente, On a Proposal, 310. 
similar); second that he finds no text in the Syriac, or any other Eastern, tradition that uses this verse in the context and with the purpose he seeks. His philological method is so loose that he can jump, via the modern German/English translation of a New Testament verse to the Roman Catholic Compline, and this is as far as the proof goes for a liturgical background to the Sura as a whole!

Sura 96 [301-25] is dealt with in much greater detail, almost every verse being re-read in some fashion or other. The two most significant re-readings are found at the beginning and end of the sura; the other readings in between, which include clay for علق and a lengthy digression on bغى are of lesser significance and will be passed over here. $^{62}$

At the start of the Sura, we find the common Qur'ānic expression قر. This, argues Luxenberg, is to be read as the Syriac homonym ${ }^{2}$ which in a liturgical context often means to call [upon God]. The point here is that the command is not read! as in from a book but call! upon God in worship. To the extent that an oral interpretation of 1 , rather than a literary one is more appropriate to a early Meccan context, Luxenberg's point here is well taken. ${ }^{63}$ Whether or not the Syriac meaning does indeed lurk behind the word as such, the positing of either a developed religious literature in the early period of Qur'ānic development (or indeed of a miraculous descent of literacy) is contextually problematic and is by no means suggested simply by arguing that might have originally had the sense of call! rather than read! or recite!

The argument for a (Christian) liturgical context of the Sura is given its final coup de grâce in the new reading of (v19) [320,323-5]. The Ethpael of the homonymous Syriac root مi can indeed refer to receiving the Eucharist and this is how Luxenberg takes 'without any doubt' (he says) this Form VIII Arabic verb. However, as the Arabists have pointed out, this is rather the regular Christian Arabic meaning of Form V of the root (تقرّب), ${ }^{64}$ which is just what he provides as a supposed example of this usage. ${ }^{65}$

What are we to make of this significant and provocative reading? First of all one has to satisfy oneself as to whether the text stands in need of such an interpretation (note that this, as well as the re-reading of 1 , is a re-interpretation of the extant Arabic word with no textual emendation required or suggested).

\footnotetext{
${ }^{62}$ A digression here includes a plea for the consonantal equivalence of $ض$ and $\downarrow$ on the basis of certain other of his suggested readings - this is a circular argument and requires far more evidence for acceptance. Furthermore, the prefix of أرعيت is understood as if (if) on the basis of one coincidence between the Lisān and Bar Bahlūl! וحسي may mean transitory, but is never found in Syriac as a substantivised adjective meaning transitory idol. كلا taken in the sense of (all) is a typical example of [C].

${ }^{63}$ But by no means original: Jeffery, Vocabulary, 233, with even earlier references.

${ }^{64}$ De Blois, Review, 96.

${ }^{65}$ The example he chooses is from the tenth century author al-Isfahānī, who uses it to refer to the activity (in a church) of the Christian Arab poet and ambassador 'Adī ibn Zayd (on whom see I. Shahid, Byzantium and the Arabs in the sixth century (Washington, D.C., 1995), I,1,478-82), but nowhere does Luxenberg suggest the idea of following through the language and usage of such Christian Arab poets as a way of illuminating the influence of Syriac on the language of the Qur'ān.
} 
Whether or not the verse (or indeed the whole sura) stands in need of a better explanation than has heretofore been available will always be in a large measure subjective. And here, as so often in the book, there is an inevitable circularity between evidence adduced as proof for the Christian liturgical background and further readings that present themselves as possibilities on the grounds of such a theory already postulated. In this case, one would have to be already especially sympathetic to the hermeneutical key in general to accept the re-reading of what appears as an unproblematic word (and indeed Luxenberg does not even try to problematise it as such).

To this extent, the discussion of اقترب leads us onto a final summing up of the theory as whole, its merits and its limitations.

\section{The Qur'ān as a Christian Lectionary}

That قران itself is derived, both in form and original meaning, from من س accepted, ${ }^{66}$ and one would think, therefore, that Luxenberg is not on his own when he starts out upon the path to show that the Qur'ān is based on Christian ecclesiastical scripture-reading (lection).

The conclusion drawn from this seems, however, over hasty: "if Koran... really means lectionary, then one can assume that the Koran intended itself first of all to be understood as nothing more than a liturgical book with selected texts from the Scriptures (the Old and New Testament) and not at all as a substitute for the Scriptures themselves" [104]. ${ }^{67}$ Of course, this does not follow at all from the philological observation that the word قران has its roots in a Christian environment. Rather all we have discovered is that religious language tends to be shared and borrowed within a given environment. Sura 12.1-2 (These are the signs of the Manifest Book. We have sent it down as an Arabic Qur'ān) need mean no more than that religious doctrine has been provided in an Arabic reading so that it may be understood by Arabic-speakers.

Even when Luxenberg re-reads يسر (19.97) as meaning to translate [123-4], ${ }^{68}$ whether or not one accepts the semantic re-reading does not force one to accept the wider implication that the text as such is a translation of a non-Arabic text. Along with many other verses (many of which he deals with, e.g. 41.3), no more is meant than that the Qur'ān is being provided in the language of the people that it might be clear to them.

\footnotetext{
${ }^{66}$ Basic discussion in Jeffery, Vocabulary, 233-4. The same consensus still holds in the Encyclopedia of Islam ${ }^{2} \mathrm{~V}: 400 \mathrm{a}$ (article by A.T. Welch), but not all would agree, e.g. Corriente, On a Proposal, 312,n17.

${ }^{67}$ This theory in general is found elsewhere, e.g. in the arguments of Van Reeth, Le Coran et ses Scribes, who is broadly sympathetic to the Luxenberg agenda.

${ }^{68}$ Via the usual route, that the basic meaning of $ي$, to facilitate, matches one meaning of Syriac ora, which is more normally to translate.
}

Daniel King, 'A Christian Qur'ān? A Study in the Syriac background to the language of the Qur'ān as presented in the work of Christoph Luxenberg' in: Journal for Late Antique Religion and Culture 3 (2009) 44-71; ISSN: 1754-517X; Website: http://www.cardiff.ac.uk/clarc/jlarc 
The proposed thesis of a Christian lectionary origin for the Qur'ān demands, of course, some construction of an historical-cultural framework that might provide the means for the linguistic correspondences that Luxenberg posits. He attempts this in the final chapter of the revised edition [326ff.]. in which he suggests that the dialect of Mecca not only was not the same as the standardised Arabic of the grammarians and exegetes (that is not in question) but that it was an 'AramaicArabic hybrid'. ${ }^{69}$ That there is no evidence for the existence of such a dialect other than in Luxenberg's re-readings hardly needs stating, and very little time is devoted to dealing with it. In general its existence is simply assumed.

But if the author singularly fails to convince with regard to his theory of an Aramaic-Arabic hybrid and a Christian Mecca, what value is there in all the many individual observations and re-readings that he presents?

First, it should be pointed out, in contrast to some reviewers, that a philological and linguistic argument by itself could be sufficient to prove cultural contact even if it were impossible to reconstruct how that contact might have come about. Arthur Jeffery states this with regard to 'obvious' loanwords, such as Middle Persian جن etc. there is no need as such to explain how the derivation came about in order for it to be accepted any more than one needs to explain the historical reasons why English piano comes from the Italian in order to be sure that it does. Although this argument cannot of course be used as carte blanche to create any etymology one likes without a context, it would suggests that if any given Syriac reading is accepted as such without doubt on philological grounds, then this ought to be sufficient to prove the cultural contact that must have been necessary to provide it in the first place. To have produced, therefore, a book entirely philological in nature and to leave it to others to provide the historical reconstruction that it demands is no renunciation of scholarly responsibility.

Furthermore, again in the author's defence, there should be no objection to most of his expressed methods. The concept of the 'foreign word' or 'loan word' must be taken in a broad sense, as indeed it was by Jeffery himself who included under such a term not just words of wholly non-Arabic form but also "words which are genuinely Arabic and commonly used...but which as used in the Qur'ân have been coloured in their meaning by the use of the cognate languages." 70 In many other linguistic contexts, in fact, the idea of 'loan shifting' (Lehnprägung) and 'loan extension' (Lehnbedeutung), by which the semantic ranges of words in the target language are moulded by the semantic ranges of perceived equivalents in the source language (which may be an equivalent only in one specific area), has been productively used in the analysis of 'loanwords' more

\footnotetext{
69 The suggestion, found in this context [327], that the name Mecca derives from the Syriac word for low-lying is as random as any an ancient etymologist might manage. It is comparable to Jerome, who took the name Aram to mean 'a high place' on the basis of the root poi! In fact, the root of Mecca is evident from Ptolemy (Corriente, On a Proposal, 314).

${ }^{70}$ Jeffery, Vocabulary, 39. Examples include نور in the sense of religion and apostle (ruelr).
}

Daniel King, 'A Christian Qur'ān? A Study in the Syriac background to the language of the Qur'ān as presented in the work of Christoph Luxenberg' in: Journal for Late Antique Religion and Culture 3 (2009) 44-71; ISSN: 1754-517X; Website: http://www.cardiff.ac.uk/clarc/jlarc 
generally. ${ }^{71}$ This essentially covers Luxenberg's methods $\mathrm{C}$ and $\mathrm{E}$ of which he makes plentiful use throughout the study.

This paper has aimed to restrict itself largely to the issue of the Syriac philology in Luxenberg's discussions, and it is here that we shall draw some final conclusions. For we have seen again that although the broad outlines of the method are not objectionable in and of themselves, nonetheless their application is so loose and so often fraught with difficulty that they entirely fail to convince in the majority of cases. In the examples given in this paper (and these by no means exhaust their sum total, although we have dealt with many more than most earlier reviewers) we have seen time and again how the method works in practice essentially the dictionaries are trawled for meanings that approximate to what Luxenberg wants to find already in the verse in question. First retro-translation to Syriac is 'achieved' by taking the generally understood Arabic meaning and finding possible Syriac glosses for it; second, the newly-discovered Syriac Hintergrund is searched (throughout all available lexica) for any other Arabic equivalents which approximate to what was sought in the first place; this meaning is then taken to be what the original Arabic expression must have meant when it existed within the 'Aramaic-Arabic hybrid'. Anyone who has spent much time in dictionaries of either language will know how many glosses can sometimes be found for a given word, and it is hardly surprising that he usually finds what he was looking for, especially when he feels free to add into the mélange any amount of diacritic shifting, in either Syriac or Arabic (or both), or even to assume a Garshuni intermediary. Furthermore, the use of the lexica of Bar 'Alī and Bar Bahlūl, which are often quoted at length in Payne Smith's Thesaurus, should be used with great caution for sixth/seventh century usage, since they reflect rather the semantic equivalents pertaining in the literary culture of the tenth century rather than the religious milieu of seventh century Arabia. Similarly, the dictionary of Eugene Mannā, used with great gusto throughout the book, reflects the common equivalences of a much later age and in no way provides a solid grounding for historical philological enquiry. These are flaws in method which need to be expunged.

Lacking any real possibility of a stemmatic or genetic investigation into the early stages of the Qur'annic text due to lack of (published) materials, the route of conjectural emendation is the only one that lies open - and Luxenberg cannot be criticised simply for setting out upon such a path. In any large collection of suggested emendations to an ancient text, there will always doubtless be a large

${ }^{71}$ There is an important discussion of the linguistic terminology relating to loanwords in Werner Betz, Deutsch und Lateinisch, Die Lehnbildungen der althochdeutschen Benediktinerregel (Bonn, 1949). The same system has also been productively used also by e.g. E. Haugen, The Norwegian Language in America: A Study in Bilingual Behaviour (Indiana Univ. Press, $2^{\text {nd }}$ ed., 1969), 38991, 400-1, and by M. Deeg, "Creating Religious Terminology - A Comparative Approach to the Early Chinese Translations" in Journal of the International Association of Buddhist Studies, forthcoming.

Daniel King, 'A Christian Qur'ān? A Study in the Syriac background to the language of the Qur'ān as presented in the work of Christoph Luxenberg' in: Journal for Late Antique Religion and Culture 3 (2009) 44-71; ISSN: 1754-517X; Website: http://www.cardiff.ac.uk/clarc/jlarc 
number that are rejected by subsequent scholarship as well as a few that endure. The situation with this book is no different. We have noted from time to time readings which do indeed make better sense than traditional interpretations and which may well be accepted - some of these involved only a rearrangement of diacritics within the Arabic word without recourse to the Syriac; others did involve the latter but carried the conviction that is born of simplicity and explanatory power.

In connection with Luxenberg's emendations, a brief word is in order on one of its repercussions which he does not fail to draw out explicitly [330], for the emendations presuppose, even without the meta-theory about the language of the Qur'ān per se, that the early history of the Qur'ān was a textual and not an oral one. This is a theory that has been argued elsewhere and on other grounds. ${ }^{72}$ Luxenberg's more successful emendations lend it further support. That he suggests that this written tradition involved a Garshuni intermediary before the written Arabic text is far more doubtful (the Garshuni technique is unlikely to have existed at so early a date), but this latter is a theory which is being developed for future publications, and is not fully worked out in this book.

Luxenberg's meta-theory of Qur'ānic origins is not proved by the evidence he sets forth in this book. That certain of the Qur'ān's expressions and words (as well as broader ideas and themes) are of Christian origin is well-founded, and should in general be sufficient to explain the data presented here without needing recourse to either of the two more radical theories he espouses, namely that the Qur'ân was in origin no more than a Christian lectionary, and that the language it which it is written is an 'Aramaic-Arabic hybrid'. More must be offered to convince anybody as to the mechanisms by which such a strong cultural and linguistic contact could have occurred. ${ }^{73}$

\footnotetext{
72 Donner, Quranic Furqān, but read alongside the recent arguments of U. Rabin, "On the Arabian Origins of the Qur'ān: The case of Al-Furqān.” Journal of Semitic Studies 54 (2009): 421-33.

${ }^{3}$ The almost entire lack, for instance, of reference to Christian Palestinian Aramaic as a possible conduit for Christian language into the Qur'ān is a serious weakness. CPA can often provide the intermediary required, e.g. in the descent of the name Aaron from its Hebrew/Aramaic to its Arabic form, Jeffery, Vocabulary, 283-4. 


\section{Appendix: Summary of scholarly reviews of Luxenberg ${ }^{74}$}

Baasten $^{75}$

Very positive, especially on individual readings - "in many instances he makes a convincing case." Supports the liturgical reading of Sura 108 (against us, see above under $V$ ), more sceptical of that of Sura 96. Criticises L. for lack of secondary literature and loose use of phonological rules.

\section{Corriente}

Strongly critiques L.'s theory of the hybrid language of Mecca as being without foundation either on an historical or a socio-linguistic basis. His strenuous resistance, however, to the thesis of non-oral transmission is rather a case of pleading on the basis of what 'must have been' ${ }^{76}$ and does not constitute a strong rejoinder. On that question, different views are still vying for supremacy. On individual readings, he is occasionally accepting, more often sceptical, sometimes scathing. When he says that L. is "well at home in Syriac language and literature" we would have strongly to differ! ${ }^{77}$

\section{De Blois}

Dismissive - 'a work of dilettantism'. De Blois points especially to L.'s lack of interaction with secondary literature. ${ }^{78}$ Most of his observations focus on errors of phonology, e.g. on the problematic examples of ضر بغ and discussed earlier, for both of which L.'s suggested readings involve unusual (or outrightly disallowed) consonantal equivalences. Some of his comments are unfairly harsh - e.g. on حنيف / Kaw, he accuses him simply of failing to note earlier propagators of the same suggestion. ${ }^{79}$ Similarly, the argument that rearranging the diacritical points "affords virtually limitless opportunities to reinterpret the scripture" is not as such an argument against that procedure which is generally accepted as a valid one in, e.g., the textual criticism of the Hebrew scriptures. It is often true that the "new reading does not make better sense than a straight classical Arabic reading" but by

\footnotetext{
${ }^{74}$ There has of course been a widespread response to the book, in both reviews and more general papers and articles, of which we mention here only a selection. The wider world of scholarship on the early history of the Qur'ānic text, to which the responses to Luxenberg ultimately contribute, would take us far away from the simpler point of this paper, namely to discuss the Syriac lexicography and philology of which Luxenberg avails himself. A few more reviews can be found on the Internet, at http://www.christoph-heger.de/Christoph_Luxenberg.html.

${ }^{75}$ Full references will be found in the Bibliography.

${ }^{76}$ E.g. "the very preaching of the Islamic faith (sic) and its spread in a mostly illiterate milieu necessitated the existence of that oral transmission within a limited range of variability." (p.309, italics mine).

${ }^{77} \mathrm{Du}$ Blois is closer to the mark: "he...knows enough Syriac so as to be able to consult a dictionary."

${ }^{78}$ In the later edition, Luxenberg does, in fact, discuss Lüling's book [18], although this is hardly a virtue that enhances the argument!

${ }^{79}$ I.e. principally himself, see n.11 above. 
no means always and it must be allowed that what constitutes 'good sense' is highly subjective and depends largely on whether one starts with a hermeneutic of suspicion or not.

\section{Gilliot}

Very positive with regard to the project in general. Gilliot finds L.'s philological method both coherent and persuasive - "le rigeur de la méthode est indéniable". It also converges well with his own work on the development of the Qur'ānic text. Like Baasten, he seems particularly convinced - "[ils] ont convaincu de la justesse de sa demarche" - by the re-readings of Sura 108 and 96 (ch.17), including the liturgical reading of the latter (for contra, see above), and also the crux of the Hūris. He seeks to build on L.'s philological work a little by trying his own hand at describing some of the historical reconstructions which might support it, e.g. the tradition by which Zayd ibn Thābit, the scribe of the Qur'ān, was a Jew who spoke Aramaic. ${ }^{80}$ While Gilliot is probably over credulous with regard to L.'s comparative philology, he is right not to criticise him, as others do, for remaining strictly within that field.

\section{Hopkins}

As dismissive as De Blois. The philological method is, he argues, wholly arbitrary and, as has been pointed out before, generally presupposes the results. Hopkins' observation that $\downarrow$ يحدون since the former is actually a late loaword from Arabic into Syriac seems to have been incorporated into the later editions of Luxenberg [114], although the reading does not feel any more likely for it. Hopkins does perhaps pick on the very worst examples (مكثة) and while he finds e.g. the explanation of the feminine خليفة "ad hoc and mechanical" he does not really explain how it is misconstrued. He is quite right, however, on the matter of the lack of secondary literature, as had been remarked already, ${ }^{81}$ and on the matter of historical context.

\section{Jansen}

Positive on the whole, although he admits that L. "might be wrong some of the time." However, Jansen is being highly subjective when he supports the reading on the basis that "few would disagree that resting, at least for the pious dead, is an activity much more proper than marrying maidens." Again, that the works of Ephrem "must have been widely known in the milieu in which Islam

\footnotetext{
${ }^{80}$ See also C. Gilliot, "Les 'informateurs' juifs et chrétiens de Muhammad. Reprise d'un problème traité par Aloys Sprenger et Theodor Nöldeke.” Jerusalem Studies in Arabic and Islam 22 (1998): 84-126; and ibid., "Reconsidering the authorship of the Qur'ān: is the Qur'ān partly the fruit of a progressive and collective work?" in G. S. Reynolds, ed., The Qur'ān in its Historical Context (London, 2008), 88-108.

${ }^{81}$ The mention of Goldziher's work again seems to have been heeded for the later edition [156], though its results are not incorporated into the text as a whole.
} 
came into being" is very questionable. The whole issue of the Ephremic model for the images of paradise is anyway irrelevant (as we showed above), but not as irrelevant as this reviewer's reference to Athenian drama!

\section{Neuwirth}

Deeply opposed and scathing, particularly of L.'s failure to engage in any number of scholarly discourses that pertain to his subject and theory, e.g. the study of Arabic poetry, Jewish contacts etc. She points, as we often have, to circularity as the chief fault in the argumentation per se, and the over-ease with which L. moves from linguistic observation to theological construct, e.g. in the matter of meaning Christian lectionary as such. The review is rather short and lacking in examples, however. ${ }^{82}$

\section{Stewart}

Much more positive about the possible claims of the theory and quick to point out that the thesis is nothing new (something that $\mathrm{L}$. himself is keen always to make clear, in fact). Again, he points to the lack of an historical basis for the theory as its most fundamental difficulty (a point also pressed home by Andrew Rippin in his contribution to the same conference volume). Most important of all, however, is Stewart's endorsement of the project of textual emendation as such, itself either frowned upon or side-stepped by most modern scholars, whether out of respect for modern Islamic views (Stewart, and others in the volume are keen, however, to point out the long tradition within Islam of conjectural emendation of the Qur'ānic text) or out of a modernistic trend to treat only with reception history (i.e. the text as understood and used by the Muslim tradition) and not with an attempt to reconstruct the historical roots of the text itself.

While he accepts a few of L.'s emendations as possible or even probable, he rejects the majority as unnecessary. He rightly points out that many of the emendations are based purely on Arabic readings and not at all on the supposed Syriac Vorlage. It is these with which Stewart deals for the most part, the general tenor of his argument being that emendation is not necessary in nearly as many cases as L. would have us believe.

\footnotetext{
${ }^{82}$ See also Neuwirth's contribution, "Zur Archäologie einer Heiligen Schrift" in C. Burgmer, Streit um den Koran (Verlag Hans Schiler, 2004), 82-87, pointing especially to the unsophisticated nature of such theses since they assume the Koran to be homogeneous and entirely explicable on a single interpretative model. For the most part such mainstream Koranic scholars have (understandably) continued their work with little more than the occasional glance toward the Luxenberg theory.
} 


\section{References}

Corriente, F., "On a Proposal for a 'Syro-Aramaic' reading of the Qur'ān." Collectanea Christiana Orientalia 1 (2004): 305-314.

De Blois, F., "Review of Luxenberg, Die Syro-Aramaische Lesart des Koran." Journal of Qur'anic Studies 5 (2003): 92-97.

Donner, F. M., “Quranic Furqān.” Journal of Semitic Studies (2007): 279-300.

Griffith, S., "Christian Lore and the Arabic Qur'ān: the Companions of the Cave in Surat al-Kahf and in Syriac Christian tradition." In G. S. Reynolds, ed., The Qur'ān in its Historical Context. London, 2008: 109-137.

Hopkins, S., "Review of Luxenberg, Die Syro-Aramaische Lesart des Koran." Jerusalem Studies in Arabic and Islam 29 (2003): 377-80.

Jeffery, A., The Foreign Vocabulary of the Qur'ān. Baroda, 1938. [Reprint, Texts and studies on the Qur'ān 3. Leiden: Brill, 2007].

Luxenberg, C., "Weihnachten im Koran (Sura 97).” In C. Burgmer, ed., Streit um den Koran. Die Luxenberg-Debatte. Standpunkte und Hintergründe, 3rd edition. Berlin, 2006: 62-68.

Reynolds, G. S., "Introduction: Qur'ānic Studies and its Controversies.” In G. S. Reynolds, ed., The Qur'ān in its Historical Context. London, 2008: 1-25.

Stewart, D. J., "Notes on medieval and modern emendations of the Qur'ān." In G. S. Reynolds, ed., The Qur'ān in its Historical Context. London, 2008: 225-248.

Van Reeth, J. M. F., "Le Coran et ses Scribes." In C. Cannuyer, ed., Les Scribes et la Transmission du Savoir. Brussels, 2006: 67-82. 